\title{
Estabelecimento de escores histopatológicos de lesão hepática e determinação dos valores normais das enzimas aspartato aminotransferase e creatina quinase em frangos de corte*
}

\author{
LUCAS BRUNELLI DE MORAES \\ Carlos Tadeu Pippi Salle (Orientador - UFRGS) \\ Banca: Benito Guimarães de Brito (UEL), Félix Hilário Díaz González (UFRGS), Luis Cesar Bello Fallavena (ULBRA)
}

A aflatoxicose é uma doença causada pela ingestão de aflatoxinas, as quais constituem um grupo de metabólitos altamente tóxicos e carcinogênicos, produzidos principalmente pelos fungos Aspergillus flavus e Aspergillus parasiticus. O mecanismo de ação das micotoxinas na célula animal ocorre na maioria das vezes, através de alterações dos processos metabólicos básicos e de alterações da função mitocondrial, da síntese protéica e de ácidos nucléicos, sendo este último um dos principais sítios de ação das aflatoxinas. A aflatoxicose pode se apresentar de duas formas. A forma aguda se caracteriza por desordem hepática, hemorragias e alta mortalidade; e a crônica, pela queda na produção, penas arrepiadas, paralisia imunossupressão e diarréia. Foram estudados 18 lotes de frangos de corte com 28 dias de idade, provenientes de seis produtores de nível bom produtivo, seis de nível médio e seis produtores de baixo nível de produção; totalizando 180 aves. As aves foram pesadas e sacrificadas, sendo coletadas amostras de fígados e de soros. Os fígados foram fixados em formalina a $10 \%$, para análise histopatológica e congelados a $-20^{\circ} \mathrm{C}$ para teste de ELISA. Das amostras de soro foram realizados testes de dosagem enzimática de aspartato aminotransferase (AST) e creatina quinase (CK) na tentativa de confirmar a lesão hepática. Os cortes histológicos de fígado foram analisados e escores de lesão estabelecidos para necrose e vacuolização dos hepatócitos, hiperplasia dos ductos biliares e infiltração periportal de células inflamatórias. Os escores de cada lesão foram comparados com os níveis de aflatoxina obtidos pelo teste de ELISA, com o peso das aves e com os valores de AST e CK. Além disso, foram comparados os níveis de aflatoxina com o peso dos frangos e com os valores enzimáticos. Por fim, estes valores de AST e CK foram relacionados com o peso dos frangos. Foi possível concluir que, nas condições estudadas, os escores de lesões hepáticas são inversamente proporcionais aos níveis de aflatoxina detectados nos fígados de frangos com 28 dias de idade. Observou-se também, que não há relação entre os valores de AST, em função dos níveis de lesão hepática e dos valores de aflatoxina detectados; e a dosagem de AST não se presta como teste preliminar para detecção de lesão hepática causada pela ingestão de aflatoxina em frangos de corte aos 28 dias de idade.

Descritores: aflatoxicose, lesões hepáticas, aspartato aminotransferase, creatina quinase, enzimas frangos.

Apresentada: 10 março 2004

*Dissertação de Mestrado n. 371 (Especialidade: Sanidade Avícola). 46f. Programa de Pós-graduação em Ciências Veterinárias da Faculdade de Veterinária - UFRGS, Porto Alegre/RS. CORRESPONDÊNCIA: L.B. Moraes: [lucasbmoraes@yahoo.com.br] 


\title{
Establishment of the histopathologics scores from hepatic lesion and determination of the normal values of enzymes aspartate aminotransferase and creatine kinase in chickens**
}

\author{
LUCAS BRUNELLI DE MORAES \\ Carlos Tadeu Pippi Salle (Adviser - UFRGS) \\ Committee: Benito Guimarães de Brito (UEL), Félix Hilário Díaz González (UFRGS), Luis Cesar Bello Fallavena (ULBRA)
}

\begin{abstract}
Aflatoxicosis is a disease that is caused by the ingestion of aflatoxines, which constitute a group of highly toxic and carcinogenics metabolites mainly produced by the fungus Aspergillus flavus and Aspergillus parasiticus. The action mechanism of the micotoxins in the animal cell happens, in the majority of the times, through alterations in the basic metabolic processes and in the mitocondrial function, of the protein and nucleic acids synthesis. The nucleic acids synthesis is one of the main sites of the aflatoxines action. Aflatoxicosis may present in two distinct ways: the acute form is characterized by hepatic disorder, bleeding and high mortality; and the chronic form is caracterized by production decrease, shivered feathers, palsy, imunossupression and diarrhea. It was studied 18 portions of 28 days old chickens from six producers of good level, six of medium level and six producers of low-level production; adding 180 birds up. The birds were weighed and sacrificed and it was collected samples of liver and blood. The livers underwent fixation in formaline $10 \%$, for histopathological analysis and were frozen at $-20^{\circ} \mathrm{C}$ for ELISA test. From the serum samples it was made aspartate aminotransferase (AST) enzimatic dosage and creatine kinase (CK) enzimatic dosage in order to attempt hepatic lesion confirmation. The histological sections were analyzed and it were settled lesion scores for necrosis and vacuolization of the hepatocytes, hyperplasia of the biliary ducts and periportal infiltration by inflammatory cells. The scores for the lesions were compared to the aflatoxin levels obtained through ELISA test, to the birds weight and to the AST and CK values. Besides, it were compared the aflatoxin levels, the chicken weight and the enzymatic values. Finally, these AST and CK values were related to the chickens weight. It was possible to conclude that, under the studied conditions, the ratio of hepatics lesions scores are reversed to the aflatoxin levels detected in the 28 days old chickens livers. It was observed that there is no relation between the AST values related to the hepatic lesion levels and to the detected aflatoxin values; and the AST dosage doesn't fit as a preliminary test for detecting hepatic lesion caused by the aflatoxin ingestion in 28 days old chicken.
\end{abstract}

Key words: aflatoxicosis, hepatic lesions, aspartate aminotransferase, creatine kinase, enzimes, chickens. 